\title{
HASRAT EKONOMI POLITISI DAN PENURUNAN KUALITAS DEMOKRASI INDONESIA JELANG PEMILU 2019
}

\author{
Johanis Putratama Kamuri \\ Rohaniawan Gereja Reformed Injili Indonesia dan Pengajar \\ Sekolah Tinggi Teologi Reformed Injili Internasional
}

\begin{abstract}
This article rests on the thesis that economic interest is the implicit end of Indonesian political agents. Economic interest, the implicit end, is the main driving force that causes the deterioration of the quality of Indonesian democracy. Various phenomena that cause the deterioration of the quality of Indonesian democracy will be understood and explained through the political strategies of Niccolo Machiavelli as a conceptual framework. Furthermore, the ideal political perspective from Bernhard Sutor which is sustained by Marx's idea of basic and superstructure will be used to find the implicit end which moves politicians and influences existing political phenomena. This article concludes with a number of thoughts that remind and prepare Indonesian society, especially the readers, to seriously consider their political choices in April 2019, in order to improve the quality of Indonesian democracy.
\end{abstract}

KEYWORDS: The implicit end, Indonesian democracy, economic interests, Indonesian politicians, Indonesian political situation, Machiavelli.

ABSTRAK: Artikel ini bertumpu pada tesis bahwa hasrat ekonomi adalah tujuan implisit agen politik di Indonesia. Hasrat ekonomi yang menjadi tujuan implisit adalah kekuatan utama yang menyebabkan penurunan kualitas demokrasi di Indonesia. Pemikiran Niccolo Machiavelli merupakan bingkai konseptual untuk memahami dan menjelaskan sejumlah fenomena politik yang memengaruhi penurunan kualitas demokrasi di Indonesia. Selanjutnya perspektif politik ideal dari 
Bernhard Sutor yang ditopang oleh konsep basis dan superstruktur dari Marx akan digunakan untuk menegaskan tujuan implisit, visi/tujuan politik, yang menggerakkan politisi dan melatarbelakangi fenomena politik tersebut. Artikel ini diakhiri dengan sejumlah pemikiran yang mengingatkan dan memersiapkan masyarakat Indonesia, khususnya pembaca, untuk memertimbangkan pilihan politiknya pada April 2019 secara serius, demi peningkatan kualitas demokrasi di Indonesia.

KATA-KATA KUNCI: Tujuan implisit, demokrasi Indonesia, hasrat ekonomi, politisi Indonesia, situasi politik Indonesia, Machiavelli.

\section{Pendahuluan}

Tulisan ini bertujuan untuk memahami dan menjelaskan salah satu faktor yang menjadi kekuatan penggerak utama dari berbagai kebijakan atau tindakan politisi di ruang publik politik Indonesia, yang memengaruhi situasi politik dan yang berkontribusi bagi penurunan kualitas demokrasi di Indonesia jelang Pemilu 2019 yang diselenggarakan pada 17 April 2019.

Divisi riset The Economist menunjukkan Skor Indeks Demokrasi Indonesia mengalami penurunan. ${ }^{1}$ Indeks demokrasi diukur berdasarkan lima faktor: pemilihan umum dan pluralisme, kebebasan sipil, fungsi pemerintahan, partisipasi politik, dan budaya politik. Negara-negara terobservasi diklasifikasikan ke dalam satu dari empat kategori ini: demokrasi penuh (full democracy), demokrasi yang cacat (flawed democracy), rezim hibrida (hybrid regime), dan rezim otoriter (authoritarian regime). Indeks Demokrasi Indonesia menurun dari peringkat 48 di tahun 2016 ke peringkat 68 pada 2017. Ini adalah penurunan terburuk dari 167 negara terobservasi, dan menempatkan Indonesia sebagai negara dengan demokrasi yang cacat (flawed democracy).

1 Risqi Bachtiar, “Menurunnya Kualitas Demokrasi.” Detik.com Kolom, 5 Maret 2018. Diakses 24 Desember 2018, https://news.detik.com/kolom/d-3899136/menurunnya-kualitasdemokrasi. 
Buruknya kualitas demokrasi Indonesia diidentifikasi melalui berbagai fenomena politik yang terjadi jelang Pemilu 2014 dan yang berlanjut ke Pilkada DKI Jakarta bahkan sampai menjelang Pemilu 2019. Kampanye hitam dengan berbagai klaim yang tidak dapat dipertanggungjawabkan kebenarannya, ujaran kebencian, hoaks, politisasi agama, dan politik transaksional yang bermuara pada praktek korupsi yang masif, menjadi fenomena yang tidak asing bagi mereka yang mengamati situasi politik melalui media massa maupun media sosial.

Fenomena politik ini tidak dapat dilepaskan dari peran politisi sebagai subyek dari berbagai tindakan politik. Maka pertanyaannya adalah bagaimana strategi politik yang tampak melalui berbagai tindakan politisi di ruang publik politik Indonesia dapat dipahami? Apa yang menggerakkan politisi untuk melakukan berbagai tindakan yang memengaruhi penurunan indeks demokrasi Indonesia tersebut? Pertanyaan pertama dapat dijelaskan melalui pemikiran politik Machiavelli, sedangkan jawaban dari pertanyaan kedua dapat ditemukan dengan memanfaatkan perspektif politik ideal Bernhard Sutor dan konsep basis- superstruktur dari Karl Marx.

Meskipun sering diasosiasikan dengan strategi politik amoral, ${ }^{2}$ Machiavelli tidak menyangkali pendekatan politik yang bermoral. Menurut Machiavelli "there are two ways to fight: by using laws, and by using force. The former is characteristic of man; the latter, of animals. But frequently the former is inadequate and one must resort to the latter." 3 Kuasa dapat diperoleh dan dipertahankan dengan strategi manusiawi yang mengandalkan hukum sebagai standar moral. Namun pendekatan ini kurang efektif dibanding strategi binatang liar yang ditemukan hampir dalam setiap bab dari buku Il Principle dan yang diungkapkan

\footnotetext{
2 Maurizio Viroli, Machiavelli (London, Granta: 2008), 34.

3 Niccolò Machiavelli, The Prince, trans. James B. Atkinson (Indianapolis: Hackett Publishing Company, 2008), 279.
} 
melalui berbagai strategi politik yang mengandalkan kekerasan dan tindakan tidak bermoral.

Kejujuran, integritas, ketulusan dan kemampuan mengendalikan perkataan adalah kualitas yang penting bagi politisi. Namun Machiavelli juga menegaskan bahwa "a prince, therefore, need not actually have all the qualities I have enumerated, but it is absolutely necessary that he seem to have them." ${ }^{4}$ Paradoks dalam komentar ini merupakan moderasi dua strategi sebelumnya. Machiavelli tidak sedang menganjurkan atau menentang moralitas maupun amoralitas dalam berpolitik. Ia menekankan pentingnya kemampuan memanfaatkan kualitas moral manusia untuk mencapai tujuan politik yakni kekuasaan.

Strategi ketiga, moderasi, adalah cara pikir akan digunakan untuk memahami dan menjelaskan situasi politik Indonesia, karena keagungan karakter dan moral dalam strategi manusia sulit ditemukan dalam konteks politik Indonesia, sedangkan strategi binatang liar sulit diimplementasikan dalam iklim demokrasi dan budaya masyarakat Indonesia.

Strategi machiavellian yang cenderung menghalalkan segala cara untuk memeroleh kekuasaan merupakan antitesis pemikiran politik Bernhard Sutor. Menurut Sutor, politik memiliki tiga dimensi dengan hubungan resiprokal: tujuan (policy), sarana (polity) dan aksi (politics). Tujuan (visi) merupakan target utama yang menstrukturkan aksi politik dan pemilihan sarana politik. Aksi adalah langkah konkret untuk mencapai tujuan politik, sedangkan sarana disesuaikan dengan tujuan untuk memudahkan aksi. ${ }^{5}$ Ini berarti hubungan resiprokal tiga dimensi politik tidak meniadakan fakta bahwa tujuan, di dalam kognisi politisi, adalah kekuatan utama yang memengaruhi tindakan dan menentukan pemilihan sarana.

\footnotetext{
$4 \quad$ Ibid., 279, 283.

5 Haryatmoko, Etika Politik dan Kekuasaan (Jakarta: Penerbit Buku Kompas, 2003), 25-8.
} 
Menurut Sutor, seharusnya tujuan politik adalah keadilan dan kesejahteraan rakyat. Tujuan ini akan terekspresi melalui penentuan kebijakan, tindakan politik dan pemilihan sarana dalam berpolitik. ${ }^{6} \mathrm{Aksi}$ politik dan sarana yang mencederai keadilan dan merugikan masyarakat tidak mungkin dihasilkan oleh tujuan politik yang mulia: keadilan dan kesejahteraan rakyat.

Tindakan politik dan pemilihan sarana yang menghasilkan berbagai fenomena yang memengaruhi penurunan kualitas demokrasi Indonesia, yang disebutkan sebelumnya, tidak mungkin dihasilkan oleh tujuan ideal yang dibicarakan Sutor. Situasi tersebut lebih mungkin dihasilkan oleh agen-agen politik machiavellian yang menghalalkan segala cara demi kekuasaan yang akan dimanfaatkan untuk mengakses tujuan tertinggi yang tersembunyi dalam kognisi dan yang, secara implisit, menyatakan diri melalui berbagai tindakan maupun fenomena politik yang ditemukan di Indonesia.

Tujuan implisit, di dalam kognisi, adalah penggerak utama dari tindakan agen-agen politik, termasuk di Indonesia. Ini adalah tujuan yang ingin dicapai politisi Indonesia dengan mengakses kekuasaan. Tujuan implisit perlu ditemukan untuk memeroleh pemahaman memadai tentang situasi politik aktual di Indonesia. Pemikiran Karl Marx-yang menggunakan konsep basis dan superstruktur untuk memahami dan menjelaskan berbagai fenomena hidup manusia, termasuk politik-dapat dijadikan solusi. Menurut Marx, proses berpikir untuk menciptakan berbagai ide yang diekspresikan dalam bahasa politik, hukum, agama dan moralitas dikondisikan oleh berbagai kekuatan dan aktivitas produksi, ${ }^{7}$ bahkan cara produksi ekonomi atau aktivitas ekonomi adalah penentu arah setiap periode sejarah politik dan intelektual. $^{8}$ Ini berarti ekonomi adalah kekuatan utama yang

\footnotetext{
6 Ibid., 25.

7 Karl Marx and Frederick Engels, German Ideology, ed. R. Pascal (New York: International Publishers, Inc., 1939), 13-4.

8 David Trueblood, Filsafat Agama (Jakarta: PT. Bulan Bintang, 1994), 97.
} 
menggerakkan sejarah dan berbagai dimensi kehidupan termasuk politik. Dengan kata lain, perilaku manusia dalam berbagai dimensi hidupnya distrukturkan oleh ekonomi.

Ekonomi merupakan bingkai konseptual utama dalam memahami kehidupan sosial di zamannya. Pemikiran Marx tentang peran ekonomi dalam menstrukturkan dunia mental dan aktivitas eksternal manusia ini akan digunakan untuk menentukan tujuan implisit, kekuatan utama, yang menggerakkan berbagai tindakan politisi yang bersumbangsih bagi penurunan kualitas demokrasi Indonesia. Tujuan tersebut adalah hasrat atau kepentingan ekonomi, bukan keadilan dan kesejahteraan rakyat.

Tujuan implisit yang dibicarakan dalam penelitian ini tidak ditawarkan sebagai perspektif determinatif atau satu-satunya penjelasan mengenai motivasi yang menggerakkan politisi Indonesia. Penelitian ini menawarkan salah satu perspektif untuk memahami situasi politik Indonesia dan kekuatan utama yang menggerakkan fenomena tersebut. Penjelasan diberikan melalui beberapa bagian utama: pendahuluan yang mendeskripsikan masalah dan tujuan penelitian, metode penelitian yang digunakan untuk mencapai tujuan penulisan, dan deskripsi terkait situasi politik Indonesia jelang Pemilu 2019 berdasarkan kerangka pikir Machiavelli. Selanjutnya akan dipaparkan temuan penelitian yakni tujuan implisit yang membentuk perilaku politisi dan yang memengaruhi penurunan kualitas demokrasi Indonesia. Sesudah itu sejumlah saran akan diberikan untuk memerbaiki kualitas demokrasi Indonesia. Tulisan diakhiri dengan kesimpulan.

\section{Metode Penelitian}

Fenomena yang mendeskripsikan tindakan politisi dan situasi politik yang memengaruhi penurunan kualitas demokrasi Indonesia akan dipaparkan dan diinterpretasi menggunakan pemikiran Machiavelli, khususnya strategi politik yang melibatkan moderasi pendekatan manusia dan pendekatan binatang liar. Akan ditunjukkan bahwa usaha merebut kekuasaan dengan memanfaatkan keagungan karakter dan 
moral lebih efektif karena iklim demokrasi dan pengaruh budaya malu di Indonesia.

Perspektif politik ideal Sutor akan digunakan untuk menunjukkan bahwa tindakan politisi dan situasi politik Indonesia tidak ideal karena tujuan atau visi politisi Indonesia tidak ideal. Tujuan yang ingin dicapai melalui kekuasaan bukan keadilan dan kesejahteraan masyarakat. Selanjutnya konsep basis dan superstruktur akan digunakan untuk memertajam pemahaman dengan menemukan tujuan implisit (implicit end) dalam kognisi politisi.

Tujuan implisit adalah kekuatan utama yang menggerakkan politisi dan melatarbelakangi berbagai fenomena politik yang berkaitan dengan penurunan kualitas demokrasi di Indonesia. Tujuan ini dapat dipahami melalui tindakan politis dan pemilihan sarana politik, maka sejumlah data terkait tindakan dan pemilihan sarana akan kembali diberikan untuk menjelaskan dan memerkuat temuan penelitian ini.

\section{Fenomena Politik di Indonesia}

Sejak pertama kali diselenggarakan pada 1955, Pemilu 2019 adalah pesta demokrasi terbesar dalam sejarah Indonesia, sebab ini adalah pemilu serentak pertama di mana masyarakat memilih presiden, wakil presiden dan anggota legislatif secara serentak. Awalnya pemilu dilaksanakan hanya untuk memilih anggota legislatif, sedangkan presiden dan wakil presiden dipilih oleh MPR. Setelah amandemen keempat UUD 1945 pada 2002, pemilihan presiden dan wakil presiden menjadi bagian dari pemilu.

Pesta demokrasi terbesar tidak selalu merupakan pesta demokrasi terbaik. Pengalaman menyelenggarakan pemilu sejak 1955 tidak menjamin bahwa Pemilu 2019 akan menjadi pesta demokrasi paling meriah dan paling baik. Pengamat dan praktisi politik justru menganggap pemilu pertama tahun 1955 sebagai pemilu terbaik karena 
tingginya partisipasi masyarakat, tidak ada bentrokan antarkonstituen partai politik, dan tidak ada penyogokan kepada pemilih. ${ }^{9}$ Sementara itu pemilu terakhir, yang dilaksanakan pada 2014, yang seharusnya menjadi pemilu terbaik karena pengalaman menyelenggarakan pesta demokrasi, justru oleh Victor Silaen ${ }^{10}$ dianggap sebagai pemilu terburuk karena diwarnai politik uang, kampanye hitam maupun terbelahnya masyarakat Indonesia.

Lalu bagaimana dengan Pemilu 2019? Fakta penurunan Indeks Demokrasi Indonesia dan sejumlah fenomena politik yang berlangsung selama lebih dari satu dekade terakhir adalah ancaman serius bagi demokrasi Indonesia jelang Pemilu 2019 yang tentunya diharapkan menjadi pesta demokrasi terbesar dan terbaik. Kampanye hitam dengan berbagai klaim yang tidak dapat dipertanggungjawabkan kebenarannya, ujaran kebencian, hoaks, politisasi agama, dan politik transaksional yang bermuara pada praktek korupsi yang masif adalah pengalaman keseharian dalam ruang publik politik Indonesia. Jika fenomenafenomena politik ini terus berlanjut, Pemilu 2019 dapat menjadi yang terburuk sejak 1955 dan kualitas demokrasi terus merosot.

Fenomena politik memiliki kaitan erat dengan strategi politik yang digunakan politisi untuk memenangkan kontestasi. Sebab itu setelah Pemilu 2014, Victor Silaen secara spesifik menunjuk politisasi agama, agama dilibatkan terlalu dalam ke politik ${ }^{11}$ karena dimanfaatkan sebagai sarana politik, sebagai penjelasan terhadap fenomena politik di Indonesia. Sedangkan Antoni Putra merujuk pada politik SARA dan kebencian ${ }^{12}$ sebagai penyebab turunnya kualitas demokrasi Indonesia.

\footnotetext{
$9 \quad$ Eep Saefulloh, Mencintai Indonesia dengan Amal: Refleksi atas Fase Awal Demokrasi (Jakarta: Penerbit Republika, 2004), 67.

10 Victor Silaen, “Kristen dan Kenaifan Politik: Kritik atas Sikap Politik PGPI dalam Pilpres 2014" dalam Societas Dei: Jurnal Agama dan Masyarakat 02 no. 1 (April 2015): 191. 11 Ibid.

12 Antoni Putra, "Penurunan Kualitas Demokrasi" dalam Koran Jakarta.com, 30 Agustus 2018. Diakses 24 Desember 2018, http://www.koran-jakarta.com/penurunan-kualitasdemokrasi/.
} 
Tetapi situasi politik Indonesia sangat kompleks sehingga penurunan kualitas demokrasi terkait pelaksanaan pemilu tidak dapat dijelaskan hanya dengan merujuk kepada satu faktor determinatif. Tanpa negasi terhadap dua pemikiran di atas, artikel ini menawarkan pemikiran politik Machiavelli sebagai bingkai konseptual untuk memahami situasi politik dan penurunan kualitas demokrasi Indonesia, karena pemikiran ini lebih luas dari perspektif yang ditawarkan Antoni dan Silaen. Bahkan dua perspektif tersebut dapat dikategorikan ke dalam satu dari tiga faktor dalam perspektif machiavellian yang ditawarkan dalam penelitian ini. Meski bukan perspektif komprehensif, perspektif machiavellian cukup memadai untuk memberi pemahaman terhadap fenomena politik yang memengaruhi penurunan kualitas demokrasi di Indonesia.

Pemikiran Machiavelli layak dipertimbangkan karena ide-idenya lahir dari observasi terhadap natur manusia dan sejarah politik. Observasi Machiavelli, yang dilakukan dengan mengambil jarak dari konsep religius abad pertengahan yang sangat berpengaruh saat itu, menghasilkan sejumlah pemikiran realis yang tetap relevan hingga saat ini. Strategi politik yang diartikulasikannya masih terulang dalam hampir setiap pertarungan politik menuju kekuasaan.

Hasil observasinya terhadap natur manusia dan sejarah di berbagai negara menunjukkan bahwa tindakan politik manusia selalu digerakkan oleh emosi, nafsu jahat dan kepentingan diri yang berakar dalam naturnya. ${ }^{13}$ Maka Machiavelli memandang politik sebagai seni atau strategi untuk merebut dan memertahankan kekuasaan dengan memerhatikan natur manusia dan mengendalikan atau memanfaatkan kecenderungan irasionalnya. Sebab itu Machiavelli menegaskan supremasi strategi politik atas keberuntungan. Ia menulis:

13 James B. Atkinson, Introduction to The Prince by Niccolò Machiavelli (Indianapolis: Hackett Publishing Company, 2008), 59. 
the prince who depends completely on fortune collapses in proportion to her fickleness. I also believe that the prince who makes his tactics consistent with the conditions of the times may be successful; and similarly that he whose own tactics are at odds with the times may be unsuccessful. ${ }^{14}$

Meski mengakui peran keberuntungan (fortune) sebagai salah satu penentu keberhasilan dalam kontestasi politik, Machiavelli lebih memrioritaskan peran strategi (virtue). Kekuasaan direbut dan dipertahankan melalui strategi yang tepat untuk mengendalikan dorongan irasional yang lahir dari ambisi dan nafsu liar orang-orang di sekitar kekuasaan.

Terkait dengan strategi politik, nama Machiavelli sering memunculkan persepsi negatif karena cara-cara tidak terpuji yang ditawarkannya. Ia sebenarnya menganjurkan politisi untuk bertindak "manusiawi," dengan melakukan hal-hal baik yang menegaskan keutamaan manusia. ${ }^{15}$ Tapi ia juga menuliskan "yet it cannot be termed virtue to murder one's fellow citizens, to betray friends, and to be without loyalty, mercy, and religion; such methods can cause one to win power."16 Ini adalah strategi binatang liar yang amoral. Pendekatan manusiawi tidak dapat menjamin kekuasaan maka harus ditopang dengan yang kedua, strategi binatang liar. Machiavelli juga menganjurkan metode ketiga, menjadikan berbagai keutamaan manusia sebagai sarana untuk mencapai kekuasaan, yang merupakan tujuan utama politik machiavellian. Ini adalah moderasi dua metode sebelumnya.

Berbagai fenomena politik di Indonesia menunjukkan bahwa politisi Indonesia tidak hanya mengalami krisis pemikiran, moral dan integritas tapi juga tidak memiliki visi bagi masa depan dan kesejahteraan bangsa ${ }^{17}$ sebab itu strategi manusia bukan bingkai

14 Niccolò Machiavelli, The Prince, 365.

15 Ibid., 79-80, 89, 279.

16 Ibid., 181.

17 Franz Magnis-Suseno, Kebangsaan, Demokrasi, Pluralisme: Bunga Rampai Etika Politik 
konseptual memadai untuk memahami situasi politik Indonesia.

Strategi binatang liar dapat menjadi penjelasan alternatif. Namun strategi yang efektif bagi pemimpin yang berkuasa absolut ini akan mengeksplisitkan kelemahan karakter dan rendahnya moralitas maupun religiusitas politisi, sehingga dalam ruang publik politik Indonesia, metode ini akan dihindari atau diminimalisir dengan dua alasan. Pertama, natur demokrasi itu sendiri. Demokrasi menyerahkan kekuasaan di tangan rakyat sehingga kekuasaan dan kepemimpinan bergantung pada suara rakyat. Calon pemimpin dituntut untuk merebut simpati dan memeroleh kepercayaan rakyat. Cara-cara tidak terpuji dalam metode pertama, yang mengurangi simpati pemilih, cenderung dihindari politisi.

Kedua, budaya malu. Alasan ini dapat dipertimbangkan dalam konteks budaya dan politik di Indonesia. Istilah malu (shame) dapat dipahami sebagai perasaan tidak menyenangkan yang diperoleh karena melakukan sesuatu yang salah. ${ }^{18}$ Rasa malu berbeda dari rasa bersalah (guilt) karena menyadari kesalahan dalam pikiran atau tindakan. ${ }^{19}$ Rasa bersalah menekankan benar atau salahnya tindakan atau pemikiran seseorang, sedangkan rasa malu berkaitan dengan "siapa kita," terutama kekurangan dan ketidakmampuan di hadapan orang lain. ${ }^{20}$ Rasa bersalah menekankan kesadaran moral yang berkaitan dengan tindakan atau pikiran yang salah. Rasa malu menekankan efek dari tindakan yang salah yaitu persepsi atau penilaian negatif orang lain terhadap pelaku tindakan. Pada kasus kedua, fokus pelaku tindakan bukan menghindari pikiran atau tindakan yang salah tapi menghindari persepsi negatif orang lain terhadap dirinya (akibat dari pikiran dan tindakannya).

\footnotetext{
Aktual (Jakarta: Penerbit Buku Kompas, 2015), 15.

18 Sally Wehmeier, ed., Oxford Advance Learner's Dictionary (Oxford: Oxford University Press, 2000), 1224.

19 Ibid., 598.

20 Binsar J. Pakpahan, "Shameless and Guiltless: The Role of Two Emotions in the Context of the Absence of God in Public Practice in the Indonesian Context" dalam Exchange 45 no. 1 (2016), 5.
} 
Masyarakat Indonesia dan Asia, pada umumnya, distrukturkan oleh budaya malu. Di satu sisi, budaya ini membatasi politisi di Indonesia dalam menggunakan cara-cara tidak terpuji yang membangkitkan persepsi negatif dalam kognisi pemilih, memermalukan diri sendiri dan menurunkan elektabilitas. Di sisi lain, budaya malu mengondisikan politisi untuk tidak tampil apa adanya. Mereka tidak berjuang menghindari pemikiran dan tindakan yang salah. Perjuangannya adalah menghindari atau meminimalisir efek negatif dari pemikiran dan tindakan yang salah yaitu persepsi negatif masyarakat yang berpotensi menurunkan elektabilitas.

Sebab itu metode ketiga, moderasi, merupakan strategi yang cenderung digunakan politisi untuk memenangkan kontestasi politik di berbagai negara demokratis, termasuk Indonesia. Pemikiran dan tindakan yang oleh masyarakat dianggap negatif akan ditutup rapat, sedangkan hal-hal yang dianggap baik akan dimanfaatkan sebagai sarana, bukan tujuan politik. Kelemahan karakter, hasrat dan kepentingan yang tidak terpuji disembunyikan di balik statements, visi yang dikampanyekan dan tindakan yang terlihat mulia secara moral dan kultural. Fenomena ini akan sering dijumpai karena metode ketiga, menurut observasi Machiavelli, sangat efektif untuk merebut dan memertahankan kekuasaan.

Situasi ini merupakan ancaman bagi demokrasi dan tantangan bagi masyarakat Indonesia yang menentukan pilihan pada Pemilu 2019. Persoalannya bukan hal baik dan bermoral yang diungkapkan politisi dalam kampanye. Persoalannya adalah hal-hal yang didiamkan dan disembunyikan (tujuan implisit) di balik semua hal baik yang dikampanyekan secara eksplisit. Sejumlah ide realistis Machiavelli khususnya yang terkait dengan moderasi strategi akan digunakan untuk memahami strategi politik yang memunculkan berbagai fenomena penyebab menurunnya kualitas demokrasi di Indonesia. Ide-ide machiavellian itu adalah politik kehadiran dan keberpihakan, politik pencitraan dan politisasi agama. 


\section{Politik Kehadiran dan Keberpihakan}

Ketidakpercayaan rakyat adalah ancaman serius bagi politisi dalam kontestasi politik. Undang-undang dan tentara yang kuat tidak dapat berfungsi maksimal jika tidak ada kepercayaan masyarakat. Solusi bagi tantangan ini adalah politik kehadiran, karena bagi Machiavelli "one of the greatest, most effective remedies would be for the conqueror to go to them and live there in person... hence they [the peoples] have more cause to love you, if they intend to be good." 21 Dengan tidak berjarak dari rakyat, politisi menjadikan dirinya sahabat yang dicintai dan memeroleh simpati atau dukungan rakyat sehingga ia tidak mudah ditaklukkan.

Politik kehadiran adalah satu usaha merebut hati rakyat dengan menghadirkan diri dalam konteks kehidupan rakyat dan menyatakan keberpihakan sehingga rakyat tetap mencintai politisi, meski ia tidak selalu hadir secara fisik. Dalam konteks politik Indonesia, salah satu usaha untuk menghadirkan diri di tengah masyarakat, menyatakan keberpihakan dan memeroleh simpati adalah blusukan. Kata blusukan yang berasal dari bahasa Jawa dipopulerkan oleh Jokowi. Awalnya, terminologi ini mendefinisikan kegiatan inspeksi ke berbagai wilayah secara formal dan nonformal untuk melihat implementasi kebijakannya maupun untuk berkomunikasi langsung dengan rakyat. Melalui blusukan, kepercayaan masyarakat terhadap Jokowi mengalami peningkatan.

Dalam konteks persaingan politik, blusukan kemudian menjadi alat komunikasi politik dan kampanye yang efektivitasnya melampaui media sosial, karena melalui tatap muka, persoalan akar rumput dapat dikemukakan dan gagasan politisi tidak hanya tersampaikan dengan lebih jelas tapi dapat diwujudkan melalui kontrak sosial atau politik.22

\footnotetext{
21 Machiavelli, The Prince, 107-108.

22 Umar Mukhtar, "Kampanye Lewat Medsos tidak Seefektif Blusukan" dalam Republika.co.id, 8 November 2016. Diakses 24 Desember 2018, https://www.republika.co.id/berita/nasional/pilkada/16/11/01/ofyj34354-kampanye-lewatmedsos-tidak-seefektif-blusukan.
} 
Politik blusukan menjadi strategi sejumlah politisi yang berkontestasi dalam pilkada maupun pemilihan presiden (pilpres).

Melalui blusukan, kandidat tidak hanya mendekatkan diri dan menyatakan keberpihakan kepada masyarakat. Blusukan juga dapat dimanfaatkan sebagai kesempatan untuk melemparkan sejumlah isu tanpa data valid yang berpotensi menjauhkan lawan politik dari masyarakat. Isu yang dilemparkan ke ruang publik politik tidak selalu berkorespondensi dengan fakta. Aktivitas blusukan sang politisi hanya dimanfaatkan untuk membentuk persepsi bahwa isu-isu tersebut merupakan fakta yang ditemukan dalam observasi langsung di lapangan dan perjumpaan langsung dengan rakyat.

Situasi ini dideskripsikan melalui artikel berjudul Perdebatan Harga di Pasar dari Blusukan Jokowi dan Sandiaga. ${ }^{23}$ Calon wakil presiden nomor urut 02, Sandiaga Uno, dan Jokowi sebagai calon presiden nomor urut 01 sering melakukan blusukan ke pasar-pasar. Melalui blusukan, Sandiaga melemparkan isu ketidakstabilan bahkan kenaikan harga pangan di bawah pemerintahan Jokowi. Istilah "tempe setipis kartu ATM" dan "tempe sachet" digunakan untuk mendeskripsikan inovasi pedagang demi menyiasati penurunan daya beli masyarakat, peningkatan harga barang dan penjualan yang menurun. Merespons hal ini, Jokowi juga melakukan blusukan ke pasar dan menegaskan temuannya bahwa harga barang cenderung stabil dan terkendali. Kali ini Sandiaga dipersepsikan sebagai pihak yang membangun isu tanpa data yang dapat dipertanggungjawabkan.

Blusukan Sandiaga dan Jokowi menghasilkan perbedaan klaim yang tidak dapat diterima dengan logika yang sehat. Sementara Sandiaga menemukan ketidakstabilan dan kenaikan harga barang, Jokowi menemukan bahwa harga barang cenderung stabil. Berdasarkan ilmu

23 Jessi Carina, "Perdebatan Harga di Pasar dari Blusukan Jokowi dan Sandiaga” dalam Kompas.com, 9 November 2018. Diakses 24 Desember 2018, https://nasional.kompas.com/read/2018/11/09/07082651/perdebatan-harga-di-pasar-dariblusukan-jokowi-dan-sandiaga. 
logika, hal ini tidak dapat dipercaya sebab dua fakta bertentangan: "A" (ketidakstabilan dan kenaikan harga) dan "bukan A" (kestabilan harga) tidak mungkin benar secara simultan di lokasi yang sama.

Blusukan bukan lagi pendekatan administratif. Blusukan adalah strategi politik. Persoalan yang ditemukan atau dikeluhkan masyarakat dipolitisasi untuk mengonstruksi citra positif sebagai politisi yang berpihak kepada rakyat. Melalui blusukan, politisi bisa memeroleh simpati masyarakat sekaligus bisa menjatuhkan citra lawan politik dengan menunjukkan ketidakmampuannya. Situasi ini menuntut masyarakat untuk bersikap kritis sehingga persepsinya tidak dibentuk oleh isu yang tidak berkorespondensi dengan fakta.

Politik blusukan adalah salah satu bentuk dari politik kehadiran dan keberpihakan yang membedakan politisi dari lawan politik yang dipersepsikan gagal hadir dan berpihak kepada masyarakat. Taktik ini dapat dibenarkan secara moral karena hadir dan berpihak kepada rakyat adalah tanggung jawab moral politisi, sedangkan simpati dan dukungan rakyat adalah imbalannya. Selain itu taktik ini memberi kemungkinan untuk memeroleh bukti ketidakhadiran dan ketidakberpihakan lawan politik yang dapat dieksploitasi untuk memenangkan kontestasi. Persoalan moral muncul ketika strategi ini digunakan untuk memanipulasi persepsi publik melalui berbagai klaim yang tidak dapat dipertanggungjawabkan kebenarannya.

\section{Politik Pencitraan}

Istilah citra mengacu pada gambaran mental tentang realitas di dalam kognisi. ${ }^{24}$ Politik pencitraan adalah usaha memengaruhi persepsi publik dengan mengonstruksi gambaran mental positif tentang kandidat dalam kognisi masyarakat. Politik kehadiran adalah salah satu ekspresi dari politik pencitraan. Pencitraan merupakan bentuk komunikasi politik yang wajar dan tidak mungkin tidak ditemukan di setiap negara dalam

24 Lihat Sally Wehmeier, ed., Oxford Advance Learner's Dictionary, 675. 
setiap kontestasi politik. Politisi harus mempresentasikan diri, prestasi dan keunggulan programnya. Tujuannya bukan hanya memenangkan kontestasi tapi juga memberi informasi memadai tentang setiap kandidat yang berkontestasi, sebelum masyarakat menentukan pilihannya.

Politik pencitraan bersifat positif jika persepsi yang dibentuk berkorespondensi dengan fakta. Fondasi bagi pencitraan positif adalah kualitas, prestasi dan keutamaan kandidat yang dapat diidentifikasi atau dipresentasikan kepada masyarakat. Dengan sendirinya, kualitas, prestasi dan keutamaan membentuk citra positif yang meningkatkan elektabilitas. Pencitraan bersifat negatif jika tidak menggambarkan kandidat sebagaimana adanya. Pencitraan ini tidak otentik karena melibatkan manipulasi sehingga persepsi dan fakta tidak berkorespondensi. Politik pencitraan negatif adalah ancaman bagi demokrasi karena pemilih kehilangan acuan yang memadai. Politik pencitraan negatif juga menghancurkan kepercayaan masyarakat terhadap pemerintah dan sistem demokrasi yang berlangsung. Tingkat partisipasi yang rendah dalam pemilu adalah salah satu akibat dari ketidakpercayaan tersebut.

Politik pencitraan sudah dipikirkan dan dianjurkan Machiavelli jauh sebelum strategi ini menjadi diskursus menarik di Indonesia beberapa tahun terakhir. Ia menyarankan politik pencitraan positif untuk memengaruhi afeksi dan kepercayaan rakyat dan menjamin keberhasilan. Ia mengaitkan citra positif dengan lima kualitas utama manusia yakni pemaaf, iman, integritas, kebaikan, agama. Kepercayaan masyarakat diperoleh politisi yang mengusahakan lima keutamaan tersebut. Namun Machiavelli juga menyadari kecenderungan masyarakat untuk menilai berdasarkan penglihatan sehingga ia menganjurkan "a prince, therefore, need not actually have all the qualities I have enumerated, but it is absolutely necessary that he seem to have them." 25 Politisi dianjurkan untuk, setidaknya, tampak memiliki sejumlah

25 Machiavelli, The Prince, 279, 283. 
keutamaan meski tidak sungguh-sungguh memilikinya. Ini adalah politik pencitraan negatif di mana berbagai keutamaan dimanfaatkan demi tujuan politik. Persepsi dalam kognisi masyarakat dibangun melalui manipulasi sehingga tidak berkorespondensi dengan kenyataan.

Pemikiran ini dapat dimanfaatkan untuk memahami pertarungan politik di dunia maya. Media sosial memiliki kekuatan untuk menjangkau banyak orang dalam waktu yang sangat singkat. Sarana ini memungkinkan tim sukses dan pendukung bahkan tim khusus yang dibentuk untuk membangun citra positif kandidat melalui data-data yang dimiliki. Namun tidak jarang citra kandidat dibangun melalui klaim-klaim fantastis yang tidak berkorespondensi dengan fakta dan yang tidak didukung oleh data valid. Persoalannya, klaim-klaim seperti ini sulit diverifikasi karena sumber berita, di media sosial, sulit diidentifikasi oleh masyarakat.

Politik pencitraan negatif berpotensi menghadirkan disintegrasi karena tidak hanya dilakukan dengan membangun citra yang tidak berkorespondensi dengan kenyataan, tetapi juga dengan meruntuhkan citra lawan politik. Citra negatif diatribusikan pada lawan politik dengan membangun persepsi negatif melalui hoaks, isu SARA, kampanye hitam dan ujaran kebencian.

Pengamat intelijen, Wawan Purwanto, menegaskan bahwa produksi hoaks akan terus meningkat dalam pilkada serentak tahun 2018 dan Pemilihan Presiden 2019.26 Politik pencitraan negatif, yang menjadikan kekuasaan sebagai tujuan utama dan yang berpotensi menimbulkan konflik, telah dan sedang terjadi di Indonesia. Jika strategi politik machiavellian ini tidak diatasi, kualitas demokrasi di Indonesia akan terus menurun dan konflik, bahkan disintegrasi, dalam masyarakat Indonesia yang plural sulit dihindari.

\footnotetext{
26 Ambaranie M.K. Movanita, "Tahun Politik, Produksi Hoaks Diprediksi Semakin Tinggi" dalam Kompas.com, 14 Maret 2018. Diakses 24 Desember 2018, https://nasional.kompas.com/read/2018/03/14/18551201/tahun-politik-produksi-hoaksdiprediksi-semakin-tinggi.
} 


\section{Politisasi Agama}

Politisasi agama dapat dipahami sebagai tindakan untuk melibatkan agama terlalu dalam di dalam politik dengan menjadikannya sebagai isu bahkan alat politik. ${ }^{27}$ Agama adalah hal yang sakral bagi manusia, termasuk masyarakat dalam negara beragama seperti Indonesia. Kesakralan agama adalah kekuatan besar yang dapat dimanfaatkan atau dipolitisasi untuk mengonstruksi persepsi positif maupun negatif demi keuntungan politik.

Machiavelli membangun teori politik dengan mengambil jarak dari agama namun, di saat yang sama, menyadari pengaruh agama di dalam kontestasi politik. Agama adalah salah satu dari lima keutamaan yang harus dimiliki atau setidaknya tampak dimiliki politisi karena agama-bagi Machiavelli-adalah sarana politik menuju kekuasaan. Ia merujuk pada keberhasilan Ferdinand dari Aragon yang memerintah di Spanyol untuk membangun reputasi dan menaklukkan lawan-lawannya dengan memanfaatkan dalil agama dan dukungan gereja. ${ }^{28}$

Agama, dalam batas-batas tertentu, memiliki peran penting dalam ruang publik politik Indonesia. Meski bukan negara agama, sumber inspirasi bagi konstitusi negara Indonesia-UUD 1945-adalah agama. Penerimaan terhadap ide Ketuhanan yang Maha Esa sebagai dasar negara (pasal 29 ayat 1 UUD 45) memang membatasi pengaruh Islam di ruang publik Indonesia ${ }^{29}$ tetapi juga menegaskan "religiusitas" bangsa ini.

Sebab itu di Indonesia, agama memiliki pengaruh signifikan dalam ruang publik politik bahkan dapat menentukan kemenangan dalam kontestasi politik. Isu agama berpotensi dipolitisasi dan dimanfaatkan untuk memeroleh dukungan politik sekaligus menaklukkan lawan

\footnotetext{
27 Lihat Sally Wehmeier, ed., Oxford Advance Learner's Dictionary, 1017.

28 Machiavelli, The Prince, 333.

29 M. Dawam Rahardjo, "Agama di Ruang Publik Politik" dalam Societas Dei: Jurnal Agama dan Masyarakat 02 no. 1 (April 2015): 105.
} 
politik. Pada tahun 2016, Dosen Komunikasi Universitas Indonesia, Ade Armando, menegaskan bahwa isu SARA sudah digunakan oleh pihakpihak yang tidak mampu bersaing di level substantif sejak pemilihan presiden tahun 2014. Ia juga memprediksi bahwa hal yang sama akan terjadi dalam Pilkada Jakarta. ${ }^{30}$

Fenomena politik Indonesia membuktikan akurasi prediksi Armando. Isu penistaan agama dan kriminalisasi terhadap pemimpin agama, misalnya, telah digunakan untuk menyerang lawan politik dan menurunkan elektabilitasnya. Isu SARA, khususnya isu ras dan agama, maupun aksi-aksi massa atas nama agama telah memengaruhi hasil Pilkada 2017 DKI Jakarta.

Fakta bahwa isu agama secara signifikan memengaruhi hasil Pilkada Jakarta 2017 merupakan peringatan bahwa strategi yang sama berpotensi digunakan dalam Pemilihan Presiden 2019 ini. Kewaspadaan dan penolakan aktif terhadap politisasi agama dituntut dari setiap warga negara karena strategi politik machiavellian ini tidak hanya menurunkan kualitas demokrasi, tetapi membuat Tuhan seolah-olah tidak ada dalam ruang publik politik negara beragama ini.

Politik kehadiran yang menekankan kehadiran dan keberpihakan politisi maupun politik pencitraan yang mengonstruksi persepsi positif dalam kognisi masyarakat adalah bagian dari usaha memenangkan kontestasi politik. Sedangkan agama dan religiusitas adalah kapital yang dapat diandalkan karena- dalam kultur dan persepsi masyarakat Indonesia-mengindikasikan karakter dan kualitas pribadi politisi. Namun ketiga faktor tersebut akan menjadi ancaman bagi demokrasi jika dijadikan sebagai sarana bagi kekuasaan semata. Sebab itu politik kehadiran, politik pencitraan dan politisasi agama dapat menjadi fenomena-fenomena yang berkontribusi pada penurunan kualitas

\footnotetext{
30 Lutfi M. Putra, "Isu SARA Muncul karena Tidak Bisa Bertarung di Level Substansif" dalam Kompas.com, 14 Maret 2016. Diakses 24 Desember 2018, https://nasional.kompas.com/read/2016/10/14/18074251/.isu.sara.muncul.karena.tidak.bisa.b ertarung.di.level.substansif.
} 
demokrasi Indonesia. Ketiganya melatarbelakangi sejumlah fenomena seperti: penggunaan isu SARA yang berpotensi menghasilkan disintegrasi karena sangat sensitif bagi masyarakat Indonesia yang plural dan masifnya penyebaran hoaks, ujaran kebencian maupun kampanye hitam. Hal yang sama masih merupakan ancaman bagi pesta demokrasi tahun 2019.

\section{Hasrat Ekonomi: Tujuan Implisit Politisi yang Memengaruhi Fenomena Politik di Indonesia}

Menurut Bernhard Sutor, tujuan (visi) politik, sarana dan aksi politik adalah tiga dimensi politik yang saling berkaitan. ${ }^{31}$ Tujuan atau visi di dalam kognisi politisi membentuk dan menggerakkan tindakan serta menstrukturkan pemilihan sarana dan penentuan kebijakan politik. Sarana dan tindakan politik umumnya disesuaikan pada tujuan yang ingin dicapai. Jadi sarana dan aksi adalah eksternalisasi dari visi di dalam dunia mental politisi dan tujuan politik mendahului bahkan mengarahkan penentuan sarana, aksi dan strategi politik.

Keadilan dan kesejahteraan rakyat adalah tujuan politik yang seharusnya. $^{32}$ Ini berarti melalui politik, politisi mengabdi pada masyarakat dengan memerjuangkan kesejahteraannya. Jika berorientasi kepada tujuan tersebut, politisi tidak akan memilih tindakan, sarana maupun kebijakan atau strategi politik yang berpotensi menghadirkan disintegrasi bangsa dan menghancurkan pihak lain. Perspektif politik ideal Sutor merupakan bingkai konseptual yang memadai untuk memeroleh pemahaman lebih mendalam tentang situasi politik aktual, termasuk situasi politik di Indonesia.

Berbagai fenomena yang dijelaskan berdasarkan ide-ide machiavellian, pada bagian sebelumnya, merupakan petunjuk bahwa situasi politik Indonesia tidak ideal. Berdasarkan perspektif politik ideal

31 Haryatmoko, Etika Politik dan Kekuasaan, 25-8.

32 Ibid., 25. 
Sutor, dapat disimpulkan bahwa situasi tidak ideal tersebut disebabkan oleh tidak adanya tujuan atau visi ideal yang diarahkan kepada keadilan dan kesejahteraan masyarakat. Magnis-Suseno menyebutnya sebagai ketiadaan visi bagi masa depan bangsa yang dapat dikomunikasikan pada masyarakat. ${ }^{33}$ Visi ideal ditiadakan dan diganti dengan visi palsu (pseudo-vision) yang bermuara pada situasi politik yang tidak ideal.

Jika keadilan dan kesejahteraan rakyat bukan tujuan, maka pertanyaannya: tujuan politik apa yang telah menggerakkan politisi dan yang melatarbelakangi berbagai fenomena yang bersumbangsih bagi penurunan kualitas demokrasi Indonesia? Politik machiavellian yang menyatakan diri melalui berbagai fenomena politik di Indonesia adalah strategi politik yang menjadikan kuasa (power) sebagai tujuan tertinggi. Ini adalah strategi umum dalam sejarah politik sehingga tampak natural dan dapat diterima, namun bahayanya akan tampak dengan jelas jika ditempatkan dalam perspektif ideal Sutor sebagai pembanding (perhatikan tabel 1).

\begin{tabular}{|c|c|c|}
\hline Dimensi Politik & Bernhard Sutor & Niccolo Machiavelli \\
\hline Tujuan (policy) & $\begin{array}{l}\text { keadilan sosial dan } \\
\text { kesejahteraan rakyat }\end{array}$ & $\begin{array}{l}\text { merebut dan } \\
\text { memertahankan } \\
\text { kekuasaan }\end{array}$ \\
\hline Sarana (polity) & $\begin{array}{l}\text { - tatanan politik } \\
\text { (hukum dan institusi } \\
\text { pemerintah) yang } \\
\text { berkeadilan } \\
\text { - struktur sosial yang } \\
\text { berkeadilan }\end{array}$ & $\begin{array}{l}\text { - } \text { tatanan politik } \\
\text { (hukum dan institusi } \\
\text { pemerintah) } \\
\text { - struktur sosial } \\
\text { - keadilan sosial, } \\
\text { kesejahteraan rakyat } \\
\text { - keutamaan: kualitas } \\
\text { moral yang baik, } \\
\text { agama / kesalehan } \\
\end{array}$ \\
\hline Aksi (politics) & $\begin{array}{l}\text { - keutamaan: kualitas } \\
\text { moral yang baik, } \\
\text { keadilan, keberanian }\end{array}$ & $\begin{array}{l}\text { - politik kehadiran dan } \\
\text { keberpihakan, politik } \\
\text { pencitraan, politisasi }\end{array}$ \\
\hline
\end{tabular}

33 Franz Magnis-Suseno, Kebangsaan, Demokrasi, Pluralisme, 15. 


\begin{tabular}{|l|l|l|}
\hline & $\begin{array}{l}\text { rasionalitas tindakan: } \\
\text { manusia sebagai } \\
\text { tujuan }\end{array}$ & $\begin{array}{l}\text { agama } \\
\text { manusia sebagai alat } \\
\text { politik } \\
\end{array}$ \\
& $\begin{array}{l}\text { - licik, eksploitatif, } \\
\text { kejam }\end{array}$ \\
\hline
\end{tabular}

Tabel 1

Tujuan berbeda memberi hasil berbeda. Kualitas moral yang baik, yang terekspresi melalui pemilihan tindakan politik dan sarana yang benar, dihasilkan oleh tujuan politik yang benar yaitu keadilan dan kesejahteraan rakyat. Jika kuasa adalah tujuan utama maka politisasi agama, politik kehadiran dan keberpihakan serta politik pencitraan yang diekspresikan melalui tindakan licik, kejam dan eksploitatif-yang disarankan Machiavelli-tidak segan dilakukan. Bahkan manusia, keadilan sosial dan kesejahteraan rakyat, yang seharusnya dijadikan sebagai tujuan politik, dapat diturunkan ke level alat atau sarana untuk memeroleh kekuasaan.

Berbagai fenomena politik di Indonesia bukan hanya petunjuk pada situasi politik yang tidak ideal, yang menyebabkan penurunan kualitas demokrasi di Indonesia, tetapi juga petunjuk pada ironi politik bahwa tujuan utama politisi adalah kuasa, bukan keadilan dan kesejahteraan rakyat. Namun tujuan tulisan ini belum tercapai dengan merujuk pada kuasa sebagai tujuan utama politisi Indonesia karena berdasarkan naturnya, politik tidak dapat dipisahkan dari kuasa.

Politik selalu berkaitan dengan pemerintahan dan pembuatan kebijakan yang berhubungan dengan kehidupan (kesejahteraan) orang banyak di wilayah tertentu. ${ }^{34}$ Pemerintahan dan otoritas untuk membuat kebijakan publik di Indonesia tidak mungkin dilepaskan dari kuasa yang, dalam konteks demokrasi, diperoleh melalui dukungan rakyat dalam kontestasi politik. Selain itu pemegang kekuasaan tidak selalu tidak memergunakannya demi keadilan dan kesejateraan rakyat.

34 Victor Silaen, “Kristen dan Kenaifan Politik," 165. 
Hal ini menunjukkan bahwa kuasa dapat dijadikan alat untuk mencapai tujuan tertentu. Berbagai fenomena politik Indonesia - yang dijelaskan pada bagian sebelumnya - merupakan strategi untuk memeroleh kekuasaan. Namun kuasa yang diperebutkan bukan tujuan akhir melainkan alat untuk mencapai tujuan akhir. Tujuan akhir yang tersembunyi, yang ingin dicapai melalui kekuasaan, disebut tujuan implisit.

Artikel ini membedakan tujuan eksplisit (explicit end), tujuan atau visi yang diungkapkan kepada masyarakat dalam bentuk visi politik dalam kampanye dengan tujuan implisit (implicit ends) yang tidak dieksplisitkan bahkan disembunyikan di balik visi politik yang dikampanyekan. Tujuan yang diungkapkan secara eksplisit dapat berbeda dari tujuan implisit yang didiamkan. Umumnya masalah tidak terletak pada hal yang diungkapkan politisi secara eksplisit tapi pada hal yang didiamkannya. Tujuan yang diungkapkan (tujuan eksplisit) sering kali hanya menjadi sarana untuk mencapai atau menyelubungi tujuan implisit yang oleh masyarakat dan kebudayaan dianggap tidak pantas.

Tujuan yang tidak diungkapkan disebut tujuan implisit dengan dua alasan. Pertama, ia tidak dieksplisitkan, bahkan disembunyikan di balik tujuan eksplisit dan berbagai keutamaan moral. Tujuan ini terlihat jika tindakan dan kebijakan agen politik dipelajari secara saksama. Kedua, meskipun tidak diungkapkan, tujuan ini adalah tujuan akhir dan kekuatan penggerak utama yang menghasilkan berbagai fenomena politik yang menyebabkan penurunan kualitas politik Indonesia.

Jika politik dan kuasa, yang melekat kepadanya, merupakan sarana untuk mencapai tujuan implisit maka pemikiran Marx yang menempatkan politik sebagai superstruktur yang distrukturkan atau dikondisikan oleh kekuatan penggerak utama (basis) dapat dipertimbangkan sebagai bingkai konseptual untuk menemukan tujuan implisit. Marx menekankan bahwa cara produksi atau aktivitas ekonomi 
menentukan arah setiap periode sejarah dan proses sosial yang berlangsung di dalamnya. ${ }^{35}$ Berbagai dimensi hidup manusia, termasuk politik, adalah pelayan bagi aktivitas ekonomi. Dengan demikian Marx menjadikan aktivitas ekonomi sebagai mesin penggerak bagi berbagai bentuk aktivitas manusia lainnya. Ekonomi (basis) memiliki kemungkinan untuk memengaruhi atau menstrukturkan cara berpikir manusia dan berbagai bentuk eksternalisasinya termasuk perilaku dan institusi yang dibentuk manusia (superstruktur). Jadi bagi Marx, ekonomi adalah bingkai konseptual untuk memahami berbagai fenomena sosial termasuk politik.

Serupa dengan Marx, artikel ini merujuk pada ekonomi sebagai salah satu tujuan yang melatarbelakangi berbagai fenomena politik di Indonesia. Ekonomi adalah tujuan implisit yang menggerakkan berbagai fenomena politik di Indonesia. Karena tujuan implisit tersembunyi di dalam kognisi maka tujuan yang dimaksud oleh artikel ini bukan aktivitas ekonomi di luar manusia. Aktivitas ekonomi tidak menjelaskan berbagai fenomena sosial, termasuk fenomena politik di Indonesia.

Manusia melakukan apa yang dipikirkan dan memikirkan hal-hal yang diyakininya. Keyakinan di dalam diri manusia adalah penggerak tindakan. Keyakinan religius menggerakkan tindakan altruistik untuk mengorbankan uang bahkan diri untuk menolong orang lain. Keyakinan bahwa Tuhan hadir dalam setiap dimensi hidup, termasuk ekonomi, membuat pedagang menjajakan dagangannya dengan jujur, walaupun dengan sedikit kecurangan ia dapat memperbesar keuntungan.

Kekuatan utama yang menggerakkan tindakan manusia tidak bersumber dari luar. Struktur ekonomi, yang menyatakan diri dalam aktivitas produksi di luar manusia, memang memengaruhi manusia tetapi tidak determinatif. Ada kekuatan di dalam diri manusia yang menggerakkan dan yang memampukannya untuk bertindak berbeda dari hal-hal yang digariskan struktur sosial di luar diri. Kekuatan

35 David Trueblood, Filsafat Agama, 97. 
internal di dalam dunia mental manusia adalah penggerak utama aktivitas manusia. Sebab itu artikel ini berbeda dari Marx yang menekankan aktivitas ekonomi sebagai kekuatan penggerak utama. Artikel ini menunjuk pada hasrat ekonomi (economic interest) yang tersembunyi dalam kognisi politisi. Hasrat ekonomi berbicara tentang kepentingan ekonomi terutama tentang keinginan untuk memeroleh keuntungan ekonomi secara personal atau keuntungan bagi kelompok tertentu.

Kuasa yang diperebutkan dalam kontestasi bukanlah tujuan implisit, kekuatan penggerak utama, yang menggerakkan politisi (sebagai agen politik) dan memengaruhi berbagai fenomena politik yang menyebabkan penurunan kualitas demokrasi Indonesia. Tujuan implisit itu adalah hasrat ekonomi. Tesis ini didukung oleh sejumlah petunjuk. Pertama, politik transaksional. Salah satu jalan untuk berkontestasi dalam pemilu adalah partai politik. Maka sekelompok orang telah memanfaatkan partai politik untuk memeroleh keuntungan ekonomi melalui politik transaksional, meskipun pemberian dan penerimaan imbalan dalam proses pencalonan antara partai politik dan kandidat dilarang dalam UU No. 10 tahun 2016 tentang Pilkada dan UU No. 7 tahun 2017 tentang Pemilu.

Sejumlah kandidat kepala daerah yang gagal memeroleh dukungan partai mengaku dimintai uang yang mencapai puluhan miliar rupiah, jika ingin dicalonkan oleh partai tersebut. Fenomena yang sama, menurut ICW juga diberlakukan dalam pemilu legislatif. ${ }^{36}$ Situasi ini menjadikan biaya politik di Indonesia sangat tinggi, dan mengondisikan kepala daerah atau legislator terpilih untuk membayar kembali dukungan yang diperoleh dan mendapatkan kembali biaya yang telah dikeluarkan. Motif ekonomi menggerakkan tindakan dan keputusan

\footnotetext{
36 "Pencalonan Pilkada 2018 Transaksional: Penegakan Hukum Pemilu Mutlak Dilakukan" dalam Indonesia Corruption Watch, 22 Januari 2018. Diakses 31 Desember 2018, https://antikorupsi.org/id/news/pencalonan-pilkada-2018-transaksional-penegakan-hukumpemilu-mutlak-dilakukan.
} 
agen politik. Kuasa, institusi dan berbagai sarana yang ada dalam kekuasaan dimanfaatkan untuk melayani tujuan ini.

Petunjuk kedua adalah tingkat korupsi yang sangat tinggi. Korupsi merupakan konsekuensi logis dari politik transaksional dan tingginya biaya politik. Karena kandidat membutuhkan dana yang sangat besar untuk berkontestasi, para pengusaha memeroleh peluang investasi melalui dukungan dana. Proyek-proyek APBN atau APBD menjadi imbalan. Sebab itu modus korupsi yang paling sering ditangani penegak hukum adalah penyalahgunaan anggaran, sedangkan nilai kerugian negara terbesar bersumber dari modus penyalahgunaan wewenang atau kuasa. ${ }^{37}$ Selain itu sepanjang 2017, tiga puluh kepala daerah menjadi tersangka korupsi sehingga total kepala daerah yang ditangkap karena kasus korupsi pada 2010-2017 sebanyak 215 orang. ${ }^{38}$ Ini tidak termasuk sejumlah kepala daerah, anggota DPR atau DPRD dan pejabat pemerintahan lainnya yang ditangkap karena kasus yang sama selama tahun 2018.

Ketiga, perilaku politisi yang menstrukturkan cara pikir dan perilaku masyarakat melalui politik transaksional, korupsi dan biaya politik yang sangat tinggi membentuk budaya di mana uang dan kuasa dapat dipertukarkan. Uang menjadi salah satu faktor penentu kemenangan sehingga kekuatan finansial menentukan dukungan yang diperoleh dalam kontestasi. Tanpa dukungan finansial yang kuat kandidat hampir pasti tidak terpilih dan partai politik sulit memeroleh dukungan yang luas.

Kemungkinan bangsa Indonesia untuk memiliki pemimpin yang berkualitas, diperkecil oleh situasi seperti ini karena kandidat yang memiliki kualitas namun tidak memiliki sokongan dana memadai tidak

\footnotetext{
37 “Tren Penindakan Kasus Korupsi: Objek Penyalahgunaan APBD Paling Banyak Dikorupsi Oleh Kepala Daerah" dalam Indonesia Corruption Watch, 19 Februari 2018. Diakses 31 Desember 2018, https://antikorupsi.org/id/news/tren-penindakan-kasus-korupsiobjek-penyalahgunaan-apbd-paling-banyak-dikorupsi-oleh-kepala.

38 Ibid.
} 
dapat berkontestasi. Sedangkan kandidat dengan dukungan keuangan memadai menjadi kontestan yang paling berpotensi untuk memenangkan pemilihan, meski tidak memiliki kualitas dan kapabilitas. Akibatnya adalah penurunan kualitas demokrasi yang makin lama menjadi semakin buruk dan semakin sulit diperbaiki.

Tesis Marx bahwa ekonomi adalah kekuatan yang menggerakkan berbagai dimensi hidup manusia, termasuk dimensi politik, masih relevan untuk digunakan sebagai salah satu bingkai konseptual dalam memahami penurunan kualitas demokrasi Indonesia. Melaluinya tujuan implisit yang menggerakkan agen politik dan yang menyatakan diri melalui tindakannya dapat ditemukan. Tujuan itu adalah hasrat ekonomi. Kuasa yang diperoleh melalui kontestasi dipergunakan untuk mencapai tujuan ini. Segala cara-termasuk yang menyebabkan penurunan kualitas demokrasi dan yang mencederai kemanusiaan maupun kesatuan bangsa-dilakukan untuk mencapai tujuan implisit.

\section{Perbaikan Kualitas Demokrasi Indonesia}

Perbaikan situasi politik dan kualitas demokrasi adalah tanggung jawab seluruh elemen masyarakat di Indonesia sebab itu beberapa pemikiran akan diberikan untuk mencapai tujuan ini. Pertama, pemerintah bertanggung jawab merumuskan visi dan aksi yang menjamin keutuhan dan kesejahteraan masyarakat. Kekosongan visi pemerintah (eksekutif dan legislatif) yang dikeluhkan Magnis-Suseno ${ }^{39}$ tidak boleh terjadi. Sutor telah menunjukkan bahwa kesejahteraan rakyat adalah tujuan politik tertinggi sebab itu visi dan tindakan politik pemerintah seharusnya diarahkan ke tujuan ideal ini, bukan diarahkan pada keuntungan atau kepentingan pribadi atau kelompok tertentu. Visi politik pemerintah yang jelas dan ideal ini tidak hanya menumbuhkan cinta atau rasa memiliki dalam hati rakyat terhadap pemerintah dan bangsanya, memberi pengharapan kepada masyarakat untuk bertahan

39 Franz Magnis-Suseno, Kebangsaan, Demokrasi, Pluralisme, 15. 
dalam berbagai kesulitan dan memberi semangat untuk terlibat dalam proses demokrasi tetapi juga memberi arah yang jelas bagi pemerintah dalam merespons fenomena politik yang tidak ideal dalam ruang publik politik Indonesia.

Kedua, pemerintah bertanggung jawab mendukung penegakan hukum dan memerkuat posisi penegak hukum dengan menyediakan dasar hukum yang jelas. Hukum dan ketegasan penegak hukum adalah kekuatan untuk mengekang hasrat ekonomi politisi yang ingin dipuaskan melalui strategi machiavellian yang ekspresinya merugikan masyarakat, mengancam keutuhan bangsa dan berdampak buruk bagi kualitas demokrasi Indonesia.

Pelanggaran hukum-seperti penggunaan isu SARA, kampanye hitam, ujaran kebencian, hoaks dan politisasi agama yang bermuara pada tindak kekerasan atau diskriminasi pada pihak tertentu-dapat ditindak dengan tegas. Demikian juga dengan politik transaksional yang bermuara pada praktek korupsi yang masif di Indonesia. Ini adalah salah bentuk pendidikan politik yang baik bagi masyarakat sekaligus usaha membangun kepercayaan rakyat kepada pemerintah dan sistem demokrasi yang sedang berlangsung. Kekecewaan memengaruhi penurunan tingkat partisipasi masyarakat dalam proses demokrasi, termasuk pemilu, sehingga indeks demokrasi Indonesia juga dipengaruhi olehnya.

Hukum yang lemah melemahkan posisi penegak hukum dan memerkuat posisi pelanggar hukum. Sebab itu ICW, misalnya, merekomendasikan penegakan hukum yang tegas dan hukuman yang memberi efek jera oleh aparat hukum ${ }^{40}$ karena melihat bahwa pemilu telah dicederai oleh praktek korupsi. Penegak hukum memerlukan dasar hukum yang solid untuk bertindak dalam usaha mengekang hasrat ekonomi dan berbagai ekspresi liar strategi machiavellian yang menurunkan kualitas demokrasi.

40 “Pencalonan Pilkada 2018 Transaksional” dalam Indonesia Corruption Watch. 
Jika melihat situasi politik Indonesia dan berbagai fenomena yang terjadi di dalamnya, regulasi hukum yang baik dan yang memberi efek jera telah menjadi kebutuhan mendesak. Setiap elemen pemerintah yang bertanggung jawab atas kehadiran hukum yang kuat memiliki kewajiban untuk menjawab kebutuhan mendesak tersebut.

Ketiga, partai politik bertanggung jawab melakukan pendidikan politik yang memadai, baik bagi kader-kadernya maupun bagi masyarakat. Tanggung jawab memerbaiki situasi dan kualitas politik Indonesia juga ada pada partai politik. Sebab itu partai politik seharusnya tidak membiarkan kader-kadernya menggunakan strategi machiavellian yang mengancam demokrasi dan kesatuan bangsa. Partai politik juga harus memberi pendidikan politik kepada kader dan masyarakat untuk membangkitkan kesadaran bahwa keadilan dan kesejahteraan rakyat adalah tujuan tertinggi. Melaluinya partai politik menghasilkan calon-calon pemimpin yang berkualitas dan masyarakat memahami bagaimana seharusnya perebutan kekuasaan berlangsung dalam iklim demokrasi.

Keempat, politisi harus menjadi teladan. Perbaikan kualitas demokrasi tidak dapat dilepaskan dari peran personal setiap politisi sebagai agen politik. Perbaikan ini dapat dicapai jika politisi menjadi contoh bagi masyarakat yang dipimpinnya. Indonesia membutuhkan tokoh-tokoh revolusioner yang menyadari situasi politik Indonesia dan yang mau menjadi martir politik. Harus ada keinginan baik politisi untuk menghindari strategi politik machiavellian (meski cara ini hanya efektif untuk menunjukkan keagungan karakter, bukan untuk menjamin kekuasaan) dan untuk melawan kecenderungan egois di dalam dirinya sendiri, di dalam struktur masyarakat yang korup dan praktek negatif dalam politik praktis.

Kelima, masyarakat bertanggung jawab untuk terlibat secara aktif namun kritis dalam demokrasi. Demokrasi melibatkan semua elemen masyarakat. Pemilu, misalnya, tidak hanya melibatkan politisi tetapi juga masyarakat Indonesia sehingga semua elemen masyarakat bertanggung 
jawab memperbaiki situasi ini. Keikutsertaan dalam pemilu adalah salah satu bentuk dari pelaksanaan tanggung jawab ini. Keikutsertaan dalam pemilu adalah petunjuk kepada penerimaan terhadap demokrasi dan kesadaran terhadap pentingnya demokrasi bagi kelangsungan hidup bangsa. Selain itu partisipasi dalam pesta demokrasi ini mengindikasikan kepercayaan rakyat terhadap pemerintah dan terutama sistem demokrasi, yang menjadi salah satu indikator bagi indeks demokrasi satu bangsa.

Tanggung jawab ini harus dilaksanakan secara kritis. Dengan menyadari bahaya penerapan strategi machiavellian, pemilih harus bersikap kritis terhadap informasi yang diperoleh. Setiap informasi harus diuji secara kritis dan ajakan-ajakan bertindak melawan demokrasi harus dihindari.

Selain itu pemilih harus memelajari kualitas pribadi dan prestasi dari calon yang ditawarkan kepada publik. Citra kontestan yang dipersepsikan kepada publik melalui berbagai media harus diuji kebenarannya. Konstituen tidak harus memilih calon yang tidak dikenal dan tidak diketahui prestasinya. Pemilu menjadi kesempatan untuk memilih pemimpin terbaik di antara keterbatasan calon-calon yang ditawarkan.

Pelaksanaan tanggung jawab secara kritis adalah salah satu cara masyarakat untuk berpartisipasi aktif memerbaiki kualitas demokrasi di Indonesia. Merujuk Armando, calon yang memiliki kualitas dan mampu bersaing di level substantif sudah memiliki daya tawar tinggi sehingga bisa meminimalisir kemungkinan penggunaan berbagai strategi yang merusak atau menurunkan kualitas demokrasi.

Di sisi lain, sikap kritis masyarakat juga berfungsi untuk mendesak partai politik untuk membenahi diri dan melakukan kaderisasi secara serius atau merekrut politisi berkualitas demi memenangkan hati rakyat dan kontestasi. Selain itu sikap ini memberi kesadaran kepada politisi untuk berbenah karena sadar bahwa masyarakat bukan hanya tidak bodoh tetapi tidak kompromi. Rakyat mengetahui apa yang dilakukan 
politisi dan rakyat tidak diam. Dengan demikian partisipasi aktif dan kritis masyarakat menjadi salah satu sarana untuk mengendalikan hasrat ekonomi yang diekspresikan secara liar dan memengaruhi penurunan kualitas demokrasi Indonesia.

\section{Kesimpulan}

Pemilu 2019 diselenggarakan di tengah situasi politik Indonesia yang tidak ideal. Politisasi isu SARA yang berpotensi melahirkan disintegrasi dalam masyarakat Indonesia yang plural, ujaran kebencian, kampanye hitam, hoaks dan politik uang yang menyebabkan tingginya biaya politik maupun korupsi merupakan fenomena yang masif terjadi di Indonesia. Harapan untuk menjadikan Pemilu 2019 sebagai pesta demokrasi terbesar dan terbaik di Indonesia terancam oleh situasi ini.

Ancaman ini tidak dapat dilepaskan dari penerapan strategi politik machiavellian. Politik kehadiran dan keberpihakan yang menegaskan keluhuran budi politisi, politik pencitraan sebagai salah satu bentuk komunikasi politik yang efektif dan agama sebagai salah satu dimensi hidup yang sakral di Indonesia telah dipolitisasi dan digunakan secara negatif.

Bentuk positif tiga strategi ini memungkinkan masyarakat untuk mengenal kandidat yang berkontestasi dan memilih kandidat dengan kualitas terbaik. Situasi ini menjamin kualitas pemerintahan dan kualitas demokrasi suatu bangsa. Namun bentuk negatif strategi machiavellian merupakan ancaman serius bagi demokrasi dan keutuhan bangsa. Halhal yang baik dan bernilai luhur dimanfaatkan untuk menyembunyikan motivasi utama yang secara moral dan kultural dianggap tidak pantas sehingga kontestasi menuju kekuasaan dapat dimenangkan. Kuasa yang diperebutkan dalam kontestasi tidak digunakan sebagai sarana mencapai tujuan politik ideal, keadilan dan kesejahteraan rakyat, tetapi digunakan sebagai alat untuk mencapai dan memuaskan tujuan implisit politisi yakni hasrat ekonomi. Keuntungan personal dan kelompok pendukung menjadi tujuan tertinggi sedangkan keadilan dan kesejahteraan rakyat 
tidak hanya diabaikan tapi juga dimanfaatkan sebagai sarana untuk mencapai tujuan implisit.

Pemahaman terhadap situasi politik ini tidak hanya memberi peringatan tentang ancaman bagi demokrasi Indonesia tetapi juga memberi pengharapan. Hasrat ekonomi politisi yang diekspresikan melalui berbagai strategi yang mengancam demokrasi bukan ancaman terbesar. Ketidaksadaran akan situasi ini adalah ancaman terbesar. Kesadaran dan pemahaman terhadap tujuan implisit politisi dan berbagai ekspresinya memungkinkan masyarakat Indonesia untuk bertindak rasional dan memerjuangkan perbaikan kualitas demokrasi.

Perbaikan ini bukan hanya tanggung jawab partai politik, politisi maupun pemerintah dan aparatnya tetapi juga tanggung jawab masyarakat Indonesia. Langkah awal ke arah perubahan adalah keterlibatan dalam Pemilu 2019. Buruknya situasi demokrasi tidak dapat direspons dan diperbaiki dengan menarik diri dari pesta demokrasi. Keterlibatan secara kritis adalah salah satu jalan keluar.

Masyarakat harus terlibat dalam Pemilu 2019 dengan memilih kandidat yang dikenal dan diketahui kualitas dan prestasinya. Ini berarti masyarakat tidak pasif untuk menerima citra yang diatribusikan pada politisi tetapi berusaha aktif memeriksa korespondensinya dengan faktafakta. Keterlibatan dalam Pemilihan Presiden dan Wakil Presiden maupun Pemilihan Legislatif di tahun politik ini menuntut kemampuan pemilih untuk melepaskan diri dari bayang-bayang tokoh berpengaruh dan dari keterikatan terhadap partai besar maupun ideologi partai tertentu. Kualitas kandidat dan prestasinya secara personal harus menjadi acuan di dalam memilih. Kandidat seperti ini dapat ditemukan dalam partai besar maupun partai kecil dan partai lama maupun partai baru. Keterbukaan informasi di zaman ini memungkinkan pengenalan yang lebih baik.

Harus diakui bahwa demokrasi dan situasi politik Indonesia tidak ideal. Tetapi jalan keluar bagi situasi ini bukan menarik diri dari politik dan keikutsertaan dalam Pemilu 2019. Harus ada perjuangan untuk 
memerbaiki situasi ini. Dengan menarik diri, masyarakat menyerahkan masa depan bangsa dan demokrasi Indonesia kepada orang-orang yang dapat menghancurkannya. Sebab itu masyarakat harus melibatkan diri dalam pesta demokrasi terbesar dalam sejarah Indonesia tersebut untuk melaksanakan kewajiban sebagai warga negara dan hak yang diberikan oleh demokrasi serta dijamin oleh undang-undang. Keterlibatan secara kritis akan menunjukkan kepercayaan masyarakat kepada sistem demokrasi dan menghasilkan perbaikan yang progresif, karena partai politik dan politisi didesak untuk memerbaiki diri. Kesadaran terhadap militansi masyarakat yang memilih secara kritis akan mendorong partai politik dan politisi memertimbangkan aksi-aksi politik yang rasional. 